$$
\text { "EL FRENÉ|KO" }
$$
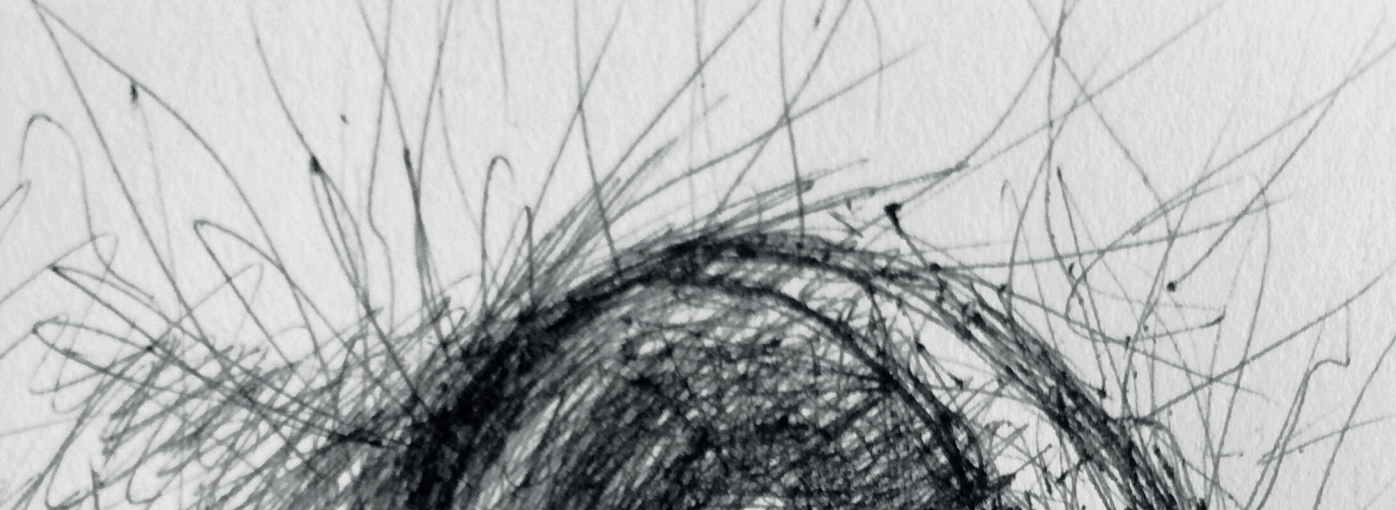

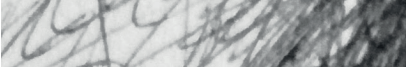
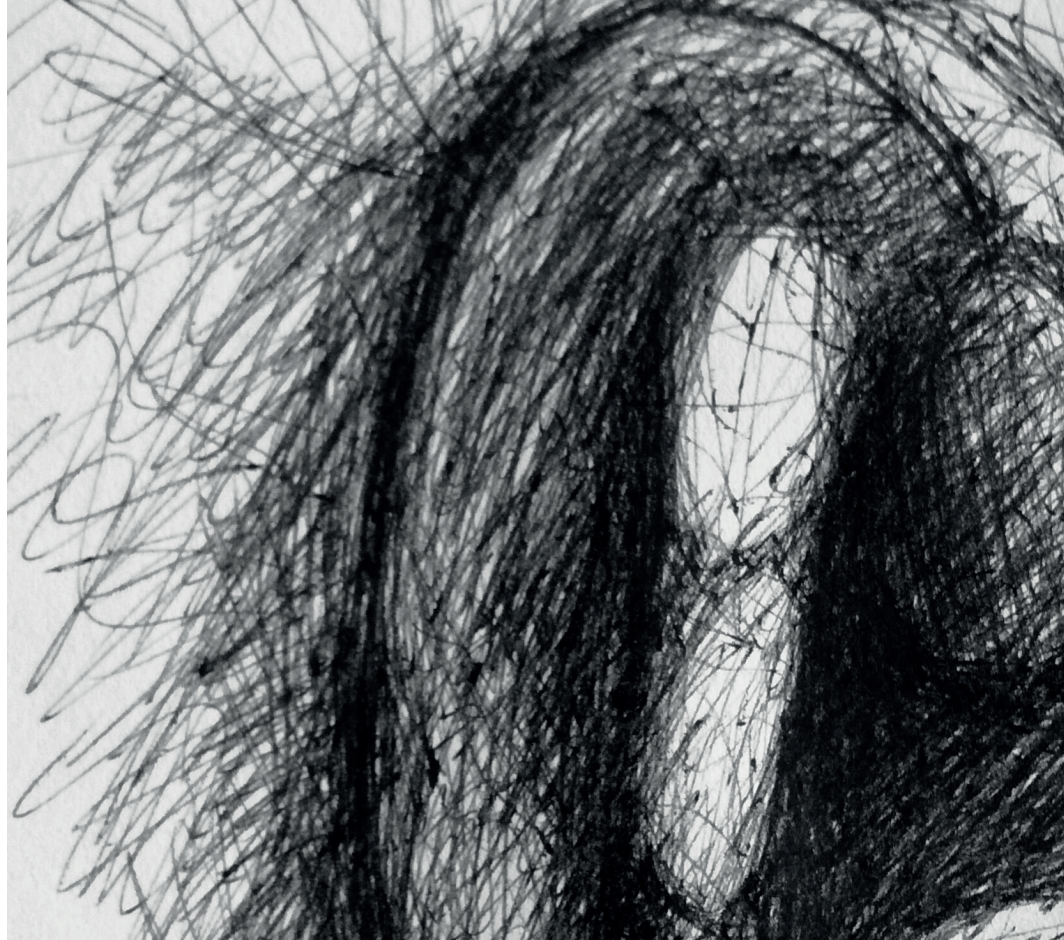

$10 \times 1019$

180012

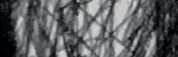

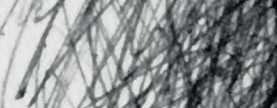
100412

1 (1)

ind

ino

$\therefore$ :

1. 19
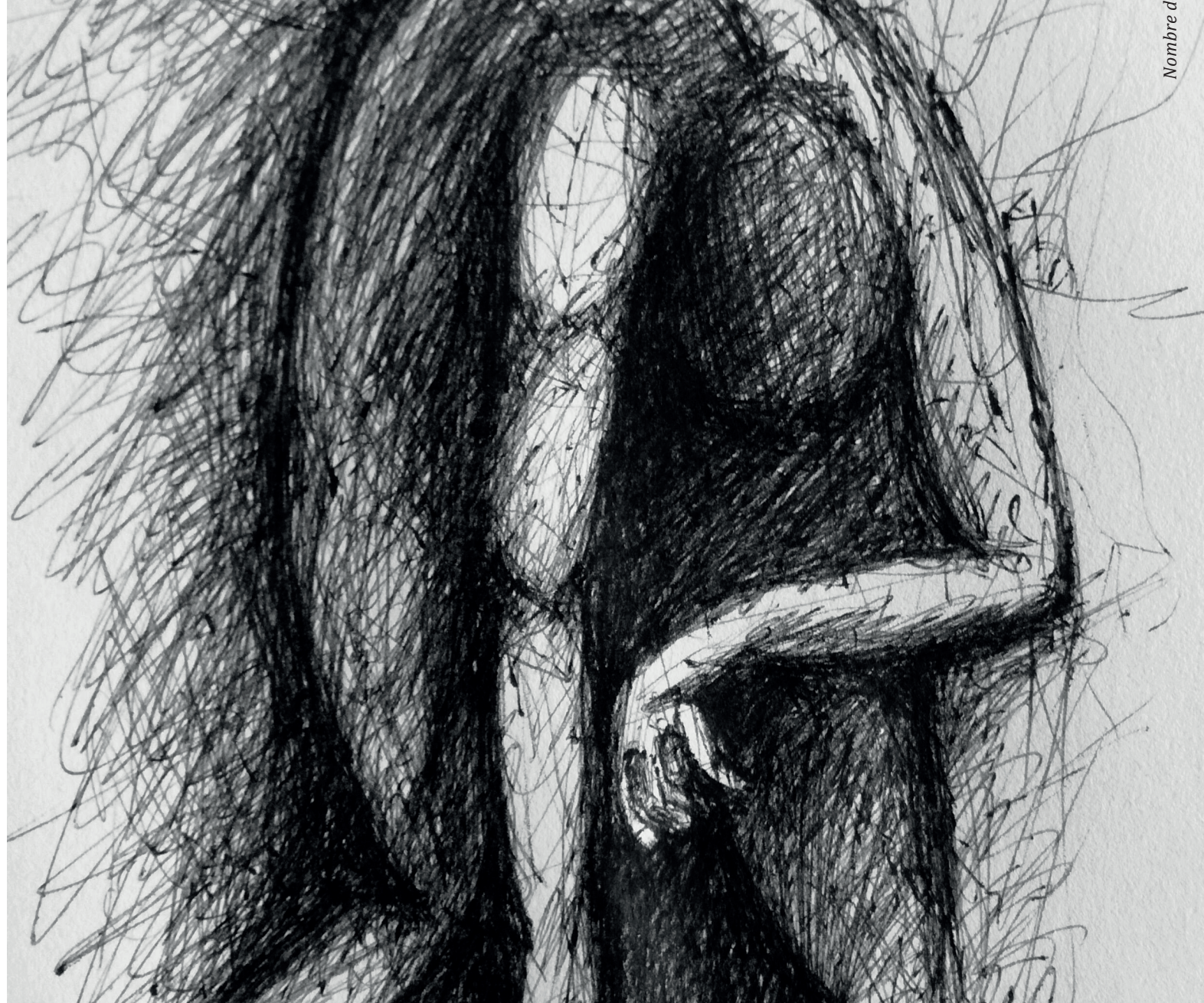

ingons

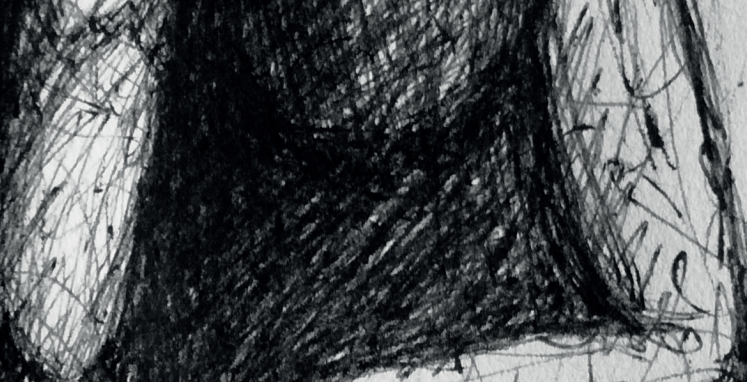

198

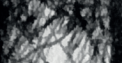

(x)
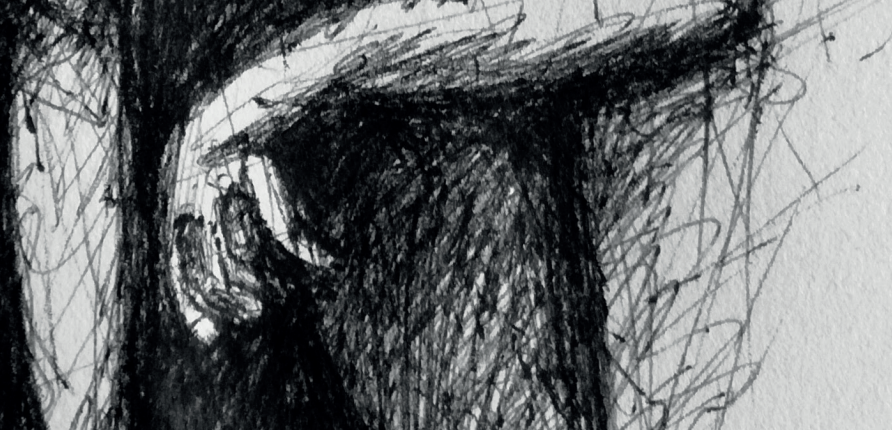

onsolit
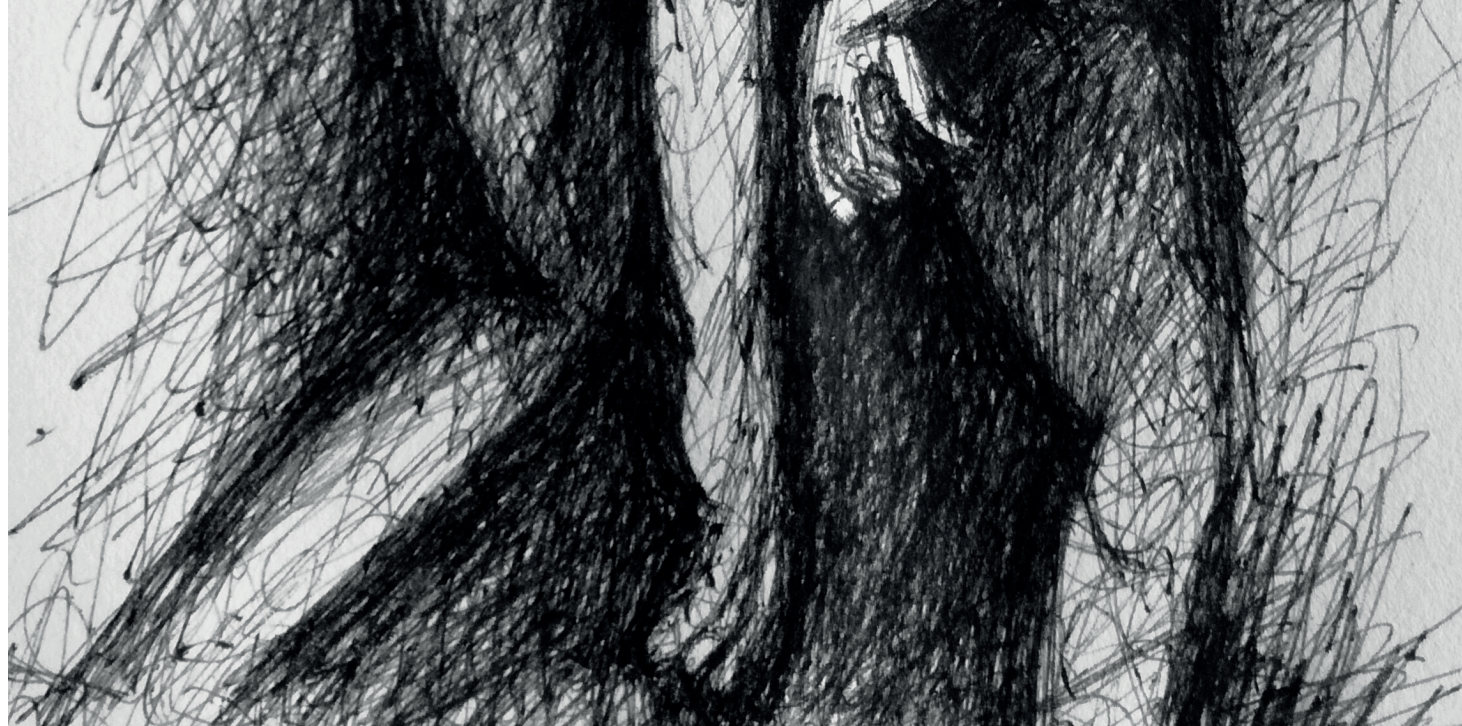


\section{Review of contractual obligations in the Civil Code of Ukraine*}

\section{Anatoliy V. Kostruba"}

\section{Abstract}

Breaching of contractual obligations may lead to certain negative consequences. Hence, this work analyzes the theoretical aspects of termination of contractual obligations in Ukraine's civil law. The article aims to study the obligation termination mechanism by determining the legal framework for its functioning. The author focuses on one of the forms of contractual obligation termination, more specifically, the start of cancellation and deferred status of a legal transaction. Using normative and protective functions in legislation, the author plans to determine specifics of legal facts of normative compensatory nature. It is established, that the condition for cancellation of a legal transaction, can be a direct or reverse mechanism for the termination of contractual obligations. A condition for cancellation of a legal transaction can be applied to the whole transaction or to its separate parts.

Keywords: Legal basis; self-organization; alienation; legal transaction; circumstance; Civil Code; Ukraine.

\section{Revisión de las obligaciones contractuales en el Código Civil de Ucrania}

\section{Resumen}

La violación de obligaciones contractuales puede causar consecuencias negativas. Por tanto el trabajo analiza los aspectos teóricos de la terminación de obligaciones contractuales en el Código Civil de Ucrania. El artículo apunta a estudiar los mecanismos de terminación de obligaciones determinando el marco legal para su funcionamiento. El autor se enfoca en una de las formas de terminación de obligación contractual, específicamente en el estatus de cancelación y diferimiento de la transacción legal. Usando funciones normativas y protectoras de la legislación, el autor busca determinar las especificidades de los hechos legales de naturaleza normativa compensatoria. Se establece que las condiciones para la cancelación de una transacción legal pueden ser un mecanismo directo para la terminación de obligaciones contractuales. Una condición para la cancelación puede aplicarse a toda la transacción o a sus partes por separado.

Palabras clave: base legal; auto organización; alienación; transacción legal; circunstancia; Código Civil; Ucrania.

\section{Revisão das obrigações contratuais no Código Civil da Ucrânia}

\section{Resumo}

Aviolação das obrigações contratuais pode causar consequências negativas. Esteartigo analisa os aspectos teóricos da terminação de obrigações contratuais no Código Civil da Ucrânia. Igualmente, visa estudar os mecanismos de terminação de obrigações determinando o quadrolegal para o seu funcionamento. 0 autor foca-se em uma das formas de terminação da obrigação contratual, especificamente no status de cancelamento e diferimento da transação legal. Usando funções reguladoras e protetoras da legislação, o autor procura determinar as especificidades dos fatos legais de natureza reguladora compensatória. Estabelece-se que as condições para o cancelamento de uma transação legal podem ser um mecanismo direto para a terminação de obrigações contratuais. Uma condição para o cancelamento pode ser aplicada a toda a transação ou a suas partes separadamente.

Palavras-chave: base legal; auto-organização; alienação; transação legal; circunstância; Código Civil; Ucrânia.

* Review article. The presented original research is completely developed and performed by Anatoliy V.Kostruba. The auth or has studied the obligation termination mechanism by determining the legal framework for its functioning.

** Doctor in Law, Associate Professor, Professor of the Department of Civil Law, Vasyl Stefanyk Precarpathian National University, Ivano-Frankivsk, Ukraine. E-mail: priminterpar@yahoo.com ORCID:0000-0001-9542-0929 


\section{Review of contractual obligations in the Civil Code of Ukraine}

\section{Introduction}

Civil contract is the main instrument for the organization of market relationships, while contractual regulation, is the traditional means of regulation of relationships, in the fields of private and public law (Parkhomenko, 1998, p. 34; Shevchenko, 2005 , p. 43). It should be added that contract, in the civil law of Ukraine, is a means of self-organization and self-regulation of civil legal relationships among their participants.

Civil law is a rather specific industry. Subjects who enter into this kind of legal relationship, at some point, commit themselves. Civil law divides obligations into contractual and non-contractual ones, which differ, significantly, from one other. Obligation, in the generally accepted and most widespread sense, is a legal relationship in which one party has rights, and the other has obligations. But such a definition cannot reveal the whole essence of the term. The Civil Code of Ukraine (CC) (Article 546) provides different types of security for the fulfillment of obligations, such as: forfeit, bail, guarantee, pledge, withholding and deposit (Civil Code of Ukraine, 2003).

Any obligation, including the contractual one, is of a temporary nature. The fulfillment of a contractual obligation, is the commission by the debtor in favor of the creditor or a third person, of certain actions -defined in the contract- that constitutes the subject of fulfillment of the contractual obligation. In order to satisfy the contractual obligation, and the termination of legal relationships between the parties, it must comply with certain general rules, which are called the principles of fulfillment of obligations (Markovits, 2015).

The way of execution of a contractual obligation, is the procedure for the debtor to take actions to fulfill the obligation (Calabresi, 2015, pp. 575-578), and as a rule; it is defined in the contract. Early fulfillment of a contractual obligation is possible, unless otherwise provided by the contract, acts of civil law or it follows from the essence of the obligation or customs of business turnover. The fulfillment of certain types of obligations requires their specificity to be taken into account.

At a certain point G.F. Shershenevich separated all methods of termination of obligations in two groups, depending on whether they are repaid, as a result of a mutual agreement between creditor and debtor, or due to circumstances 
independent of the transaction (impossibility of execution, set-off, death of one of the subjects, combination of an active and passive entity, prescription) (Shershenevich, 1915).

One of the first reasons, in the Soviet literature system, for termination of obligations in 1975, proposed by O.S. Ioffe, who, without noticing the criterion of classification, also divided them into two groups (without taking into account the reasons of general significance or those that can be applied only by direct order of the law) (Ioffe, 1948):

1) Termination of obligations as a result of their implementation (fulfillment, offset, innovation);

2) the actual termination of obligations (agreement of the parties, combination, impossibility of fulfillment, death of a citizen or liquidation of a legal entity).

Nevertheless, the division proposed by O.S. Ioffe, did not have a clear criterion for demarcation; therefore, unreasonably, different explanations were put together in one group for their grounds, since he did not cover all possible grounds at that time. The current Civil Code of Ukraine did not only expand the list of reasons for termination of the obligation, but also systematized these reasons to some extent. Simultaneously, with the adoption of the Code, a number of problems relating to the termination of the obligation were not only not resolved, but, on the contrary, new ones, due, inter alia, to changes in civil and economic legislation, were added to the existing problems.

The uniqueness of such legal aspect of contract should be explained by the fact that, on the one hand, it is capable of causing the consequences in the form of onset, change or termination of civil legal relationships or subjective civil rights, or legal obligations. On the other hand, under civil contract, both objective and subjective grounds for the movement of proprietary and binding legal relations are fixed, the occurrence of which involves onset, change or termination of rights, obligations or even new civil legal relationships between parties to contract. The terms of civil contract establish individual mechanisms for right termination of civil relationships and legal models of right-terminating legal facts.

The theoretical issues of contractual regulation of private legal relationships are the subject of numerous scientific research of such scientists as N.S. Kuznietsova (2013), R.A. Epstein (2016), D. Markovits (2015), A.B. Hryniak (2013), N. Fedorchenko (2017) and others. Nonetheless, the scientists left outside their attention, the theoretical and practical problems of formation and functioning of the mechanism of termination of contractual obligation, in the context of the theory of legal facts, which considers the grounds for such termination as individual legal facts, and their legal compositions.

The purpose of the scientific article is to study the mechanism of termination of contractual obligation, through the determination of legal structures for its func- 
tioning. By means of regulatory and protective functions in the law, it is planned to identify the special features of legal facts of regulatory and compensatory nature.

\section{Typical features of contractual obligations}

The characteristic feature of contractual obligation is the dependence of onset of legal fact in its structure, on the lawful will of party (action) of legal transaction or objective circumstance of reality (event). Its existence is provided by the legal model of certain legal fact in contract, which, in coincidence with actual circumstances established by such model, can lead to reasonable expectations of parties to the legal result and, accordingly, the termination of such obligation. By means of such legal facts, the action of regulatory function of the law is ensured, the content of which is the realization of rights and interests of parties to contractual obligation, established by terms of the relevant contract bona fides.

In the theory of the civil law in Ukraine, such legal constructions have been called, regulatory right-terminating legal facts. Among the most common, they include alienation. Alienation should be understood as the legal mechanism established by contract, for the transformation of property right to assets in accordance with its legal regime, which is accompanied by onset of actual consequences of such transformation, resulting in termination of contractual obligation.

The regulatory effect of alienation, as a right-terminating legal fact in contractual obligation, is an achievement of the purpose of legal regulation established by parties to contract. Thus, as a result of alienation, a certain owner, through his will expression implements his property right, in result of which parties of contractual obligation receive mutual satisfaction.

Moreover, the reason for termination of contractual obligation is its proper fulfillment. It consists in observance of the five established requirements, which simultaneously are conditions of onset of the given right-terminating legal fact (Civil Code of Ukraine, 2003):

1) Proper object of fulfillment (articles 610, 620, 622);

2) Proper subject of fulfillment (articles 527, 528);

3) Proper date of fulfillment (articles 530, 531);

4) Proper place of obligation fulfillment (article 532);

5) Proper manner of fulfillment (articles 529, 533).

The termination of contractual obligation by fulfillment consists in the implementation, by its parties, of subjective civil rights and fulfillment of counter legal obligations, which express the object of obligation. In this way, the purpose of legal 
regulation established in contract is achieved, that is, the satisfaction of common interests of participants in civil legal relationships. In other words, the proper fulfillment is legal composition with differentiated accumulation of its elements, the formation of which, inevitably, leads to the termination of contractual obligation.

The legal status "outside the framework of contract", has no effect on the efficiency of the mechanism of termination of contractual obligation, by the proper fulfillment.

The proper place for fulfillment of contractual obligation (article 532 of Civil Code of Ukraine) is: a) for obligations on transfer of real estate - at the place of the property location; b) for obligations on transfer of goods (property) arising from contract of carriage - at the place of delivery of goods (property) to carrier; c) for obligations on transfer of goods (property) arising on the basis of other transactions - at the place of manufacture or storage of goods (property), if this place was known to creditor as of the moment of creation of the obligation; d) for monetary obligations - at the place of residence of creditor, and if the creditor is a legal person - at its location as of the moment of creation of the obligation. If creditor changes its place of residence (location) as of the moment of creation of the obligation and informed debtor about it, the obligation is fulfilled at the new place of residence (location) of creditor, with assigning all losses related to change of place of fulfillment to creditor; e) for other obligation - at the place of residence (location) of debtor (Civil Code of Ukraine, 2003).

\section{The reason for termination of contractual obligations}

The reason for termination of contractual obligation is also transfer of payoff. The transfer of payoff is made by conclusion of legal transaction between creditor and debtor, whose purpose is to terminate the principal obligation. Such legal transaction shall confirm the achievement of agreement of parties regarding the quality and quantity of object, which is payoff, the deadline for the transfer of the payoff, the order of its transfer, as well as fixing the time of termination of the contractual obligation.

Article 604, of Civil Code of Ukraine, considers that obligations may also be terminated by agreement of parties. The cancellation of contract is condition with which partial or full termination of contractual obligation is connected, until the moment of its legal and actual fulfillment. That is, the cancellation of contractual obligation is one way of its termination. Any agreement on termination of contractual obligation has features of legal transactions, with the special feature that they are aimed at termination of subjective civil rights, and legal obligations that arose on the basis of primary contract. Consequently, 
such agreements must comply with general requirements for the lawfulness of legal transactions envisaged by article 203 of Civil Code of Ukraine. Thus, the termination of contractual obligation, by agreement of parties, is executed in the form established for the conclusion of such obligation. It should be noted that termination of contract by agreement of parties entails not only the termination of rights and obligations of its parties, but also a number of other legal consequences.

According to article 601 of Civil Code of Ukraine, contractual obligation is terminated by offset of counter uniform claims, term of fulfillment of which has expired, as well as claims, which term of fulfillment has not been set; however, it is determined by the time when claim is made. Thus, the offset implementation is possible in the presence of several conditions: a) the uniformity of civil obligations (object of both obligations must be of the same kind); b) counter character of claims in obligation (creditor of one obligation is simultaneously debtor under another obligation, and vice versa - debtor of the first obligation is creditor of the other); c) onset of time of fulfillment of civil obligations; d) conclusion of legal transaction on offset of counter uniform claims; e) fulfillment of reconciliation of offsets on the basis of uniform obligations, which are terminated by offset of counter uniform claims.

To date, there are several approaches as to the moment of onset of indicated right-terminating legal facts. According to the first, offset is considered as completed and repays set-off claims at the time of sending notification of offset to other party (Civil Code of Ukraine, 2003).

The second approach implies that civil obligation is considered to be terminated by offset, since the moment of expiry of term for fulfillment of obligation that came later. This position is substantiated by the fact that, since the expiry of termination term of civil obligation, the payment of penalty and interest ceases, because the obligations are considered to be repaid.

But the phenomenon of reciprocity of offset will lead to the fact that, before the receipt of application about it, which is, of course, necessary for the legal validity of offset, parties may be regarded as being in default. At the same time, after offset by debtor, this delaying may be, only for the party which has achieved the fulfillment of the previous obligation (Sarbash, 2001, pp. 87-88).

The third option is based on the assumption of the involvement of counterparties by offset, since the moment of reception, by addressee party of the notification. The choice of this approach will necessarily raise the question of the admissibility of recalling of offset (by analogy with the recalling of offer), until the reception of corresponding notification by the addressee. Civil obligation may also be considered terminated after the expiry of the time necessary for reception of application on offset by other party. If this party has reasons to consider it to be 
carried out in the absence or non in accordance with, at least, one of necessary conditions, such person may apply to the court for the recognition as invalid of offset and fulfillment of contract requirements (Mikhno, 2004, p. 53).

The position produced by A.V Sirotkina is appropriate (Syrotkina, 2009, p. 51). In her opinion, the termination of civil obligation by offset, unlike other types of unilateral legal transactions, entails the termination of both rights and obligations of applicant of offset as well as its counter-party.

One of the reasons for the termination of contractual obligation, in accordance with article 605 of Civil Code of Ukraine, is the release by creditor of debtor from his obligations (debt forgiveness). Based on the fact that one party - creditor has a subjective civil right, legal obligation is imposed on his counter-party - debtor that corresponds to certain subjective civil right to terminate contractual obligation, is carried out in direct and reverse order. The direct order consists in the fulfillment of legal obligation of creditor, and the reverse - in depriving the person of subjective civil right, which corresponds to such an obligation.

Debt forgiveness is characterized by the fact that creditor relieves the debtor from fulfillment of his obligations, without requiring counter-fulfillment of obligations, resulting in termination of corresponding contractual obligation. This is unconditional, unilateral legal transaction, termination of contractual obligation of which is fulfilled in reverse order.

In accordance with article 606 of Civil Code of Ukraine, contractual obligation is terminated by combination of debtor and creditor in one person (confusion). Each civil obligation implies the existence of three of its main elements: subject, object, and content. Unlike the other, the exclusion of such element of obligation as subject terminates his existence. The formula for such exclusion is the combination of debtor and creditor in one person.

When a debtor and creditor are combined in one person, the contractual obligation undergoes certain changes. One person assumes all legal properties of the other in contractual obligation, therefore; the status of participant in relevant legal relationships is terminated. Previously, existing legal bonds between parties are absorbed by the person that has joined two (or more) participants in such obligation (Chilton \& Versteeg, 2018, pp. 293-335).

By the way, citizen A. and citizen K. are parties to lease legal relationships concerning real estate. Real estate is property of citizen A., citizen K. is respectively, lessee. While in lease legal relationships, parties conclude contract of sale, which results in property being transferred to ownership of citizen $\mathrm{K}$. In this case, the conclusion of sale contract, changes lease legal relationships, as a result of which they are terminated. 


\section{Characteristics of changes in contractual obligations}

The terms in the civil law of Ukraine are of a significant legal category, which determines not only the regularization of civil circulation in time, but also ensures the possibility of fulfillment and realization by subjects of civil relationships of their rights, thus inducing, obligated persons, to perform their obligations and the possibility of the timely protection of breached rights.

The onset of term is such legal fact that may lead to the termination of contractual obligation. Its peculiarity is that it is attributed to events, even regardless of the fact that its course may depend on the will of participants in civil legal relationships.

In particular, item 5 of part one of article 1141 of Civil Code of Ukraine states that, simple partnership contract shall be terminated in case of expiry of simple partnership contract period. In this case, the right-terminating fact is the moment of expiry of simple partnership contract period. That is, the expiry of period is law-terminating legal fact (Civil Code of Ukraine, 2003).

A similar legal norm is also contained in article 2219 of the Napoleonic Code, which states that statute of limitation is a means of establishing or repaying obligation in case of onset of certain term, and in the presence of relevant conditions established by the law (Code civil, 2017).

At the same time, in legal literature, there is an opinion that the expiry of contract period cannot always be identified with the reasons for termination of obligations (Kossak, 2004, p. 17). Termination of civil obligations is legal consequence of validity of legal facts (volitional actions of participants in civil legal relationships), aimed at termination of civil rights and obligations of specific subjects. After onset of such legal fact, the civil legal relationships among these entities are terminated. This thesis is reflected in article 764 of Civil Code of Ukraine, which states that, in case when lessee continues to use property after expiry of contract of lease, then, in the absence of objections of lessor within one month, the contract is considered as renewed for the period that was previously established by contract.

Thus, part one of article 615 of Civil Code of Ukraine states that, "in case of obligation breaching by one party, the other party shall have the right to refuse, partially or totally, from obligations if it is established by contract or by law". In some cases, the exercise of right to unilateral refusal from contract is due to other circumstances that are not related to violation of contract. Their onset may be caused both by external facts and by such actions that do not have any signs of breaching of right (Obolonkova, 2010, p. 17). The provision of right to refuse from contractual obligation is always based on impossibility of achieving aim in its legal regulation. 
The given mechanism of right termination of contractual obligation causes legal consequences, as result of unilateral action of party to contract. Breaking legal relationships among participants in civil legal relationships, it ends at certain stage of their development. Such termination of contractual obligation occurs at any stage of its development, at the stage of exercise of right (Gonzalez-Zapata \& Heeks, 2015, pp. 441-452).

Part two of article 604 of Civil Code of Ukraine states that, civil obligation shall be terminated by agreement of parties, on replacement of the original obligation with a new obligation between the same parties (innovation). The innovation covers cases of termination of contractual obligation by transforming its content. It also adjusts its object. In this case, such element as subject of obligation remains unchanged (Civil Code of Ukraine, 2003).

Contractual obligation is also terminated by impossibility of its fulfillment in connection with circumstance for which neither party is responsible (article 607). Unfortunately, Civil Code of Ukraine does not establish criterion for impossibility to fulfill obligation. It is a circumstance that makes it impossible to fulfill obligation, or circumstance that has changed conditions in connection with which parties (party) cannot fulfill obligation objectively, regardless of all other circumstances. In addition, the law does not reveal the concept itself of impossibility to fulfill obligation.

With the death of natural person (the liquidation of legal entity), his legal capacity, proprietary rights and binding rights, as well as participation in contractual obligations, are also terminated.

In accordance with the general rule established by Civil Code of Ukraine, civil obligation must be fulfilled by debtor personally, unless otherwise provided for by the law or contract. The fact of the death of natural person (the liquidation of legal entity) objectively affects the stated purpose of legal regulation of relevant civil legal relationships.

\section{Features of the life cycle of a contractual transaction}

In most cases, the "life" of a legal transaction is associated with onset of unconditional factors to achieve its purpose. At the same time, parties to legal transaction have the opportunity to determine, in advance, the existence of circumstances (their presence or absence) that may affect the dynamics of contractual obligation among them. It gives the right to existence of such a legal phenomenon as conditional legal transactions. The aforesaid has in sight to minimize possible risks associated with uncertainty in development of events that determine its implementation (Fedorchenko \& Kalaur, 2017, pp. 34-39). 
In legal literature, in the division of all legal transactions into conditional and unconditional ones, legal transactions with cancellation and delayed conditions are in the first category. The two types of terms of legal transaction are traditional: conditions with delay or suspension (from lat. suspensus - suspended, delayed) and cancellation or resolution (from lat. resolutivus - final) circumstances.

Thus, according to the first and second paragraphs of article 212 of Civil Code of Ukraine, people who implement legal transactions have the right to determine onset or change of rights and obligations by circumstances concerning which it is unknown whether the (delayed circumstance) will come or not. The people who implement legal transaction have the right to stipulate the termination of subjective civil rights, and legal obligations by circumstances concerning which it is unknown whether (cancellation circumstance) will come or not (Civil Code of Ukraine, 2003).

As it is seen from the above provisions of Civil Code of Ukraine, the legislator delimits the delayed and cancellation consequences, that result in legal transactions where such circumstances are stipulated. In the projection of legal facts, the delayed circumstance has the character of right-establishing or right-changing act or event, whereas onset of cancellation condition is defined by regulations as right-terminating legal fact of contractual obligation.

At the same time, it is worth pointing out that such division is quite arbitrary, in view of the complex and relative nature of legal facts. However, the cancellation condition, in its nature, should always result in form of termination of rights, obligations, legal relationships or powers in legal relationships. The nature of delayed condition is that it is not legal transaction, but its consequences come after certain period of time, that is, they are delayed.

Thus, in accordance with part one of article 723 of Civil Code of Ukraine, deed of gift may set grantor obligation to hand over gift to grantee in the future after a certain term (within a certain period), or in case of onset of delayed condition. With regard to lease of housing with ransom, in accordance with part seven of article 810 of Civil Code of Ukraine, lease contract with ransom is the document indicating the transfer of property right to real estate from the enterprise - lessor to lessee with delayed circumstance determined by the law. In its turn, cancellation condition of legal transaction is mentioned only in one article of Civil Code of Ukraine, in addition to article 212, which is article 1142. In accordance with the second part - of which part of the simple partnership contract concluded for specified period or by contract in which the achievement of the purpose is defined as cancellation condition - the lessor has the right to demand termination of contract in relationships with other participants due to valid reason, with the reimbursement to other participants of real damage caused by termination of contract. 
It should be noted that, in view of the definition of delayed and cancellation conditions in article 212 of Civil Code of Ukraine, they can also be applied in unilateral legal transactions. The provision of again article 723 of Civil Code of Ukraine, serves in favor of this circumstance, which provides for the possibility of the existence of variance of deed of gift with the obligation to hand over the gift in the future. Thus, in accordance with part two of the aforementioned article, in case of the expiry of period (term) or the delayed circumstance established by deed of gift with the obligation to deliver the gift in the future, grantee has the right to demand from grantor to transfer gift or reimburse its value.

For the cancellation condition, onset of which is right-terminating legal fact, it is characteristic that it cannot be an essential condition of legal transaction. The explanation of this circumstance lies in the very nature of legal transaction as volitional conscious action aimed at onset, change or termination of civil rights and/or obligations. Consequently, giving the nature of the essential condition of legal transaction to cancellation condition, it actually blocks its implementation by parties. Cancellation condition at the time of legal transaction conclusion exists only in the ideal form, and in fact, in real life the relevant circumstance should arise only in the future. Herewith, it is not known for sure whether it will come or not.

Consequently, cancellation condition is certain circumstance of reality, with onset of which rights are terminated; however, at the same time, this circumstance may not depend on will of parties to legal transaction, in this regard, not circumstance should be considered as cancellation condition, but the fact of its onset. It is precisely the fact of onset of one or another condition, implementation of action, the arising of certain phenomenon is the "final point" in the process of formation, existence or termination of such phenomenon. Termination of right in legal transactions with cancellation condition is the legal consequence of reason in the form of onset of cancellation condition.

\section{Characteristic features of termination of contractual circumstances}

A characteristic feature of the referral and cancellation circumstance, onset of which is legal fact, is that they have "objectified" character and their onset must, in the majority, occur without the parties' participation in legal transaction or with their participation, but without creating obstacle for counter-party in contractual obligation. But the mechanism of right termination of contractual obligation, can act both according to objective and subjective scenario.

The general procedure for the termination of the transaction (agreement) in Ukraine requires the agreement of both parties to terminate the contract. Therefore, unilaterally terminating the contract of sale of an apartment or other real estate; 
its party will not be able to do so, unless it is directly established by the contract. As a rule, in real estate transactions, a ban on unilateral extrajudicial termination of the contract is established. If the consent of the other party is not available, or the unilateral termination is not permitted by the contract, the contract will have to be terminated in court (Petrie, 2014, pp. 75-92; Epstein, 2016, pp. 47-93). Therefore, when preparing a treaty in the text, it is necessary to stipulate the possibility of unilateral extrajudicial termination or amendment of the treaty. Termination and refusal to fulfill a contract with real estate must be made in writing. The order of registration is established in the contract or in the law.

One of the conditions, for the validity of the contract of sale and purchase of real estate as well as the main duty of the buyer, is its payment. The main mistake that the parties allow during the conclusion of a transaction is the incorrect execution of payment documents, the lack or vice of which lead to disastrous consequences. So, if the property is purchased from the organization, it is preferable to pay it only by bank transfer. If housing is bought from an individual, that is, from a citizen, the calculation must be confirmed not only by an act, but also by a receipt containing complete and understandable information about who, to whom and for what the corresponding amount of money was transferred. It should be borne in mind that the termination of a transaction cannot be invalidated. The application of the consequences of the invalidity of the disputed transaction is possible only if there is a decision to recognize such a transaction, as invalid.

There is no such legal concept as the cancellation of the contract of sale. The contract can be either terminated or invalidated (Article 651, art.652). Both mean termination of the contract. For the termination of the contract of sale of an apartment, a mutual consent of the parties is necessary (Civil Code of Ukraine, 2003).

The contract is subject to termination in case of a significant change in circumstance, from which the parties proceeded at the conclusion of the contract. A change in circumstance is recognized as significant when they have changed so much that, if the parties could reasonably foresee this, the treaty would not have been concluded at all, or would have been concluded under significantly different conditions.

Recognizing the same transaction, as invalid, is only possible in court. To do so, you need to go to court with a civil suit and provide evidence that your demands are legitimate and justified. For example, when a transaction was made in the absence of the will of the owner (by forged documents, a trustee, exceeding the powers, etc.) or a transaction committed under the influence of fraud, violence, threat, malicious agreement of the representative of one party with the other party. An invalid transaction can be recognized as a transaction committed by a citizen, though capable, but at the time of his imprisonment he was in a state where he was not able to understand the meaning of his actions and/or to manage them (alcoholic, narcotic intoxication, etc.) 
In general, it can be stated that, onset of cancellation condition of legal transaction is a right-terminating legal fact with a delayed mechanism of action. The very nature of such legal transaction determines the circumstance that there is certain period of time between the moment of its conclusion and onset of consequences (Hryniak, 2013, p. 18-29).

It should be noted that, the cancellation condition as element of contract, as well as the basis for termination of contractual obligations, may take place only within the limits of the existing legal relationships, and only within the limits of the current legal transaction. In other words, cancellation condition may be reflected as its element, when such legal transaction is actually concluded. At the same time, parties cannot agree on cancellation condition of legal transaction, if it is not the case yet, because such agreement will not have sufficient validity in order to be reflected in a future legal transaction.

It is possible to attribute to peculiarities of cancellation condition, onset of which is right-terminating legal fact in contractual obligation in legal transaction, the fact that, on the one hand, such circumstance, or rather its legal model, are considered as element of legal transaction. After it has been consolidated under terms of legal transaction, it is necessary and sufficient for the operation of such contract, although not having the character of essential condition. On the other hand, the cancellation condition is the result of the creative approach of parties to legal transaction to formation of its terms, and therefore is considered as circumstance which terminates legal relationships in relation to the fact that is reflected in legal transaction by the will of parties.

Nevertheless, the order of occurrence of legal consequences of cancellation condition may also be specified. In fact, it is possible to distinguish two orders of onset of consequences of corresponding condition of legal transaction - objective and subjective ones. Objective right termination is characterized by the fact that a contractual obligation is terminated automatically, since the moment of onset of relevant condition. For example, parties to legal transaction may foresee that rights and obligations of parties are terminated since the moment of the death of one of the parents of the lessor. In such circumstances, contractual obligation shall be deemed to be terminated since the moment of the biological death of the relevant person, regardless of all other circumstances (Bennett et al., 2018, pp. 817-878).

If, however, looking at the given situation in terms of objective termination, the legal transaction, in fact, is terminated since the moment of the relevant circumstance, regardless of whether other members of civil legal relationships learned about onset of such circumstance. At the same time, in the course of the legal transaction itself, in order to avoid misunderstandings and abuses, parties to legal transaction foresee the order of fixing and proof of the existence of cancellation condition. Both objective and subjective right termination lead to one consequence, 
but give rise to various risks. In case of subjective right termination, the relevant party receives the required amount of information regarding its condition. From the moment it is received, the party has some time to take the necessary actions to terminate completely contractual obligation and not to cause negative consequences (Kuznietsova, 2013, pp. 51-64).

In case of objective termination, the relative party may not be aware of onset of condition. During the time between the fact that the relevant condition has come and the person has learned about its onset, the party uses the benefits without sufficient legal basis, and therefore his counter-party can apply to such person, negative consequences, in the form of penal sanctions.

It should be noted that, cancellation condition of legal transaction is the construction that fits into the basic principles of functioning of the mechanism of right termination of contractual obligations, and is consistent with the procedure for fulfillment and termination of legal transactions. In particular, in our opinion, the cancellation condition may be reflected in terms of legal transaction as the basis, not only for termination of contractual obligation as a whole, but also for termination of individual rights and obligations of participants of corresponding legal relationships.

Cancellation condition of legal transaction may trigger direct or reverse mechanism of termination of contractual obligation. That is, it may terminate legal obligations in connection with termination of subjective civil law, or vice versa, may terminate subjective civil rights in connection with termination of legal obligation of the party to legal transaction. Cancellation condition of legal transaction may be applied to the whole transaction or to individual part thereof. As a consequence, cancellation condition of legal transaction may change the nature of legal relationships, make a bilateral legal transaction a unilateral one or a mixed legal transaction a singular one, etc.

\section{Conclusions}

Civil contract, in the mechanism of legal regulation of civil property relationships, is considered as an instrument of legal regulation of relevant relationships (legal remedy of self-regulation), as means of establishing of right-terminating legal facts, as well as, basically, right-terminating legal fact.

The author examined the issues of the normative effect of the mechanism for the legal termination of contractual obligations, set out the reasons for the termination of the contractual obligation, and determined the characteristics of the changes in contractual obligations. Also, the terms of termination of the legal transaction were ascertained. It is established that it is canceled, basically, as agreed by both parties. 
The author also established that, in the legal regulation of civil property relationships, the contract ensures the interests of participants in civil legal relationships, while retaining the ability to be flexible within the mechanisms of balancing interests of specific subjects of civil legal relationships, society, and State.

Legal regulation of civil property relationships is aimed at achieving the legal result determined by their participants, at the stage of exercise of right. As it turned out, at this stage, right-terminating legal facts, with the help of the appropriate mechanism of right termination, ensure the onset of consequence agreed by parties in the form of right termination.

The achievement of the purpose of legal regulation of civil property relationships, at the stage of exercise of right, is ensured by the regulatory action of the mechanism of right termination.

Such right-terminating legal facts in binding legal relationships are: alienation, the combination of debtor and creditor in one person, termination of obligations by agreement of parties, due fulfillment of civil obligations, offset of counter uniform claims, transfer of payoff, debt forgiveness, expiration of terms, and conditions of contract, etc.

The emergence of defect of legal fact, at the stage of exercise of right, leads to the impossibility, for their participants, to achieve the purpose of legal regulation of civil property relationships. The defect character of legal facts, at this stage, changes the model of legal regulation of civil legal relationships. There is replacement of the stage of exercise of right by the stage of right termination of civil property relationships.

At the stage of right termination, the compensatory effect of the mechanism of right termination is manifested, which is, in the compensation of the impossibility to remove defect of legal fact, that interferes with the achievement of the purpose of legal regulation, at the stage of exercise of right, by onset of the expected legal effect in accordance with the legal model of subjects of law, adopted by the participants of civil legal relationships.

Such compensatory right-terminating legal facts include the death of the natural person, termination of obligation at the request of one of the parties, innovation, and impossibility to fulfill civil obligation, etc.

\section{References}

Bennett, T.B., Friedman, B., Martin, A.D., Smelcer, S.N. (2018). Divide \& Concur: Separate Opinions \& Legal Change. Cornell Law Review, 103(4), 817-878. 
Calabresi, S.G. (2015). The unknown achievements of Justice Scalia. Harvard Journal of Law and Public Policy, 39(3), 575-578. Retrieved from http://harvardjlpp. wpengine.com/wp-content/uploads/2010/01/39_3_Calabresi_F.pdf

Chilton, A.S., Versteeg, M. (2018). Courts' Limited Ability to Protect Constitutional Rights. University of Chicago Law Review, 859(293), 293-335.

Civil Code of Ukraine. (2003). Retrieved from http://zakon3.rada.gov.ua/laws/ show/435-15

Code civil. (2017). Retrieved from https://constitutions.ru/?p=416.

Epstein, R.A. (2016). The Role of Guidances in Modern Administrative Procedure: The Case for De Novo Review. Journal of Legal Analysis, 8(1), 47-93.

Fedorchenko, N., Kalaur, I. (2017). Legal Regulation of Obligations on Service Delivery in the Context of the Development of Ukraine's Economy. Journal Transition Studies Review, 24(1), 34-39.

Gonzalez-Zapata, F., Heeks, R. (2015). The multiple meanings of open government data: Understanding different stakeholders and their perspectives. Government Information Quarterly, 32(4), 441-452.

Hryniak, A.B. (2013). Contractual obligations to perform work in the civil law of Ukraine. (Doctoral thesis, Jurisprudence). Institute of private law and entrepreneurship of the National Academy of Legal Sciences of Ukraine, Kyiv.

Ioffe, O.S. (1948). On some theoretical issues of civil law science. Bulletin of Leningrad University, 3, 84 - 97.

Kossak, V.M. (2004). Problems of termination of obligations under new Civil Code of Ukraine. Actual problems of state and law: collection of research papers, Legal literature, 23, 17.

Kuznietsova, N.S. (2013). Development of Civil Society and Modern Private Law in Ukraine. Private Law, 1, 51-64.

Markovits, D. (2015). Civility, rule-following, and the authority of law. Columbia Law Review. Retrieved from https://columbialawreview.org/content/civility-rulefollowing-and-the-authority-of-law/

Mikhno, O.I. (2004). Civil aspects of offset as a way to terminate contract. Problems of Legality: republican interdepartmental scientific reports, 67, 53.

Obolonkova, E. (2010). Unilateral refusal from fulfillment of obligation: classification issue. Economy and Law, 2, 17.

Parkhomenko, N.M. (1998). Contract in System of Law of Ukraine. (Author's thesis, Jurisprudence). Koretsky Institute of State and Law, Kiev.

Petrie, M. (2014). Jurisdictional integration: A framework for measuring and predicting the depth of international regulatory cooperation in competition policy. Regulation and Governance, 10(1), 75-92. 
Sarbash, S. (2001). Termination of obligations by offset в arbitrary practice. Economy and Law, 10, 87-88.

Shershenevich, G.F. (1915) Textbook of Russian civil law. Moscow: Brat'ya Bashmakovy. Shevchenko, L.I. (2005). On Concept, Essence and Meaning of Contractual Regulation of Property Relations in Market Economy. State and Law, 10, 43.

Syrotkina, A. (2009). Termination of obligations. Economy and Law, 4, 51. 